
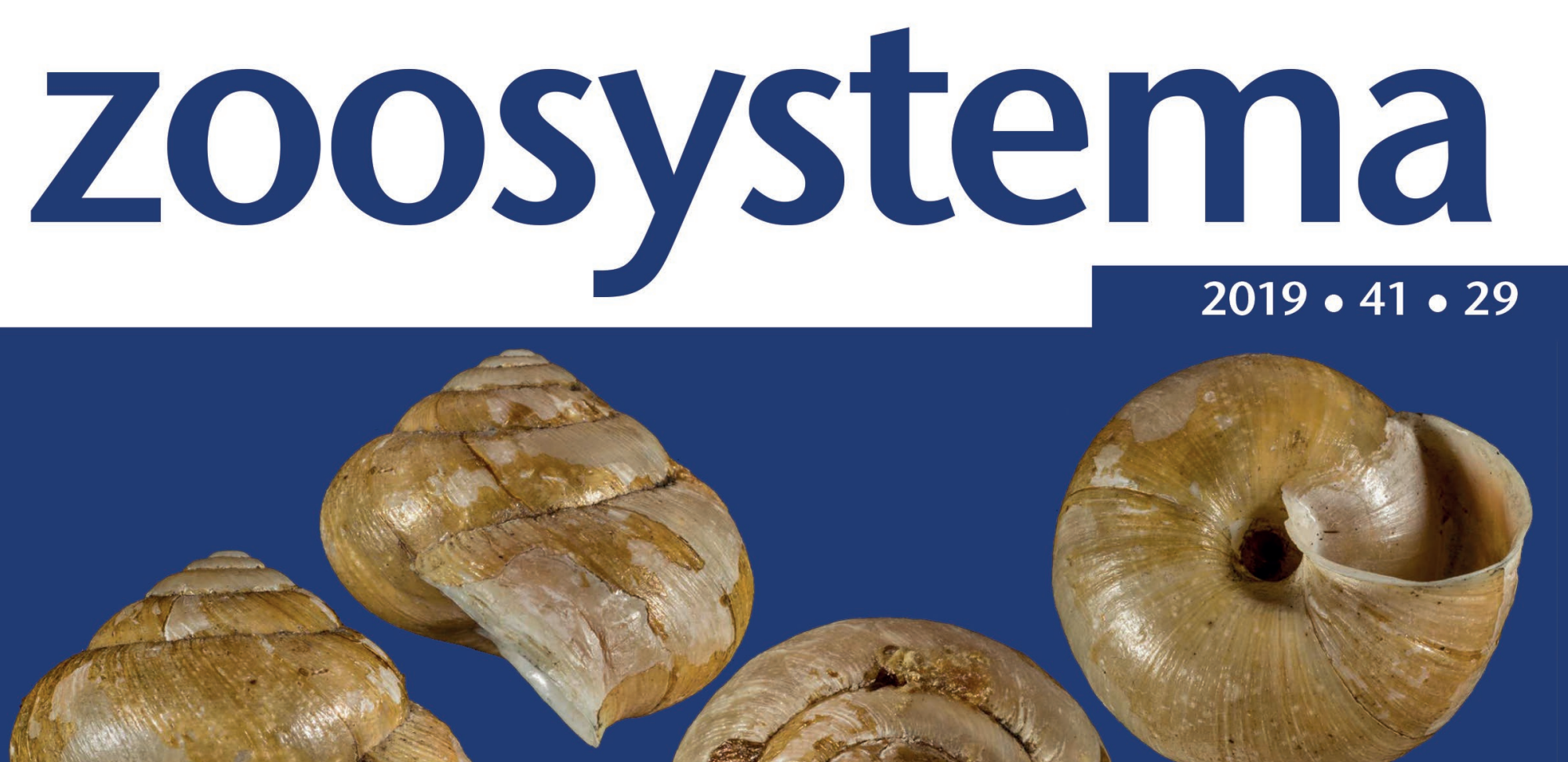

A review of the gen us Coccoglypta Pilsbry, 1895 (Gastropodá Pulmonata: Camaenidae)

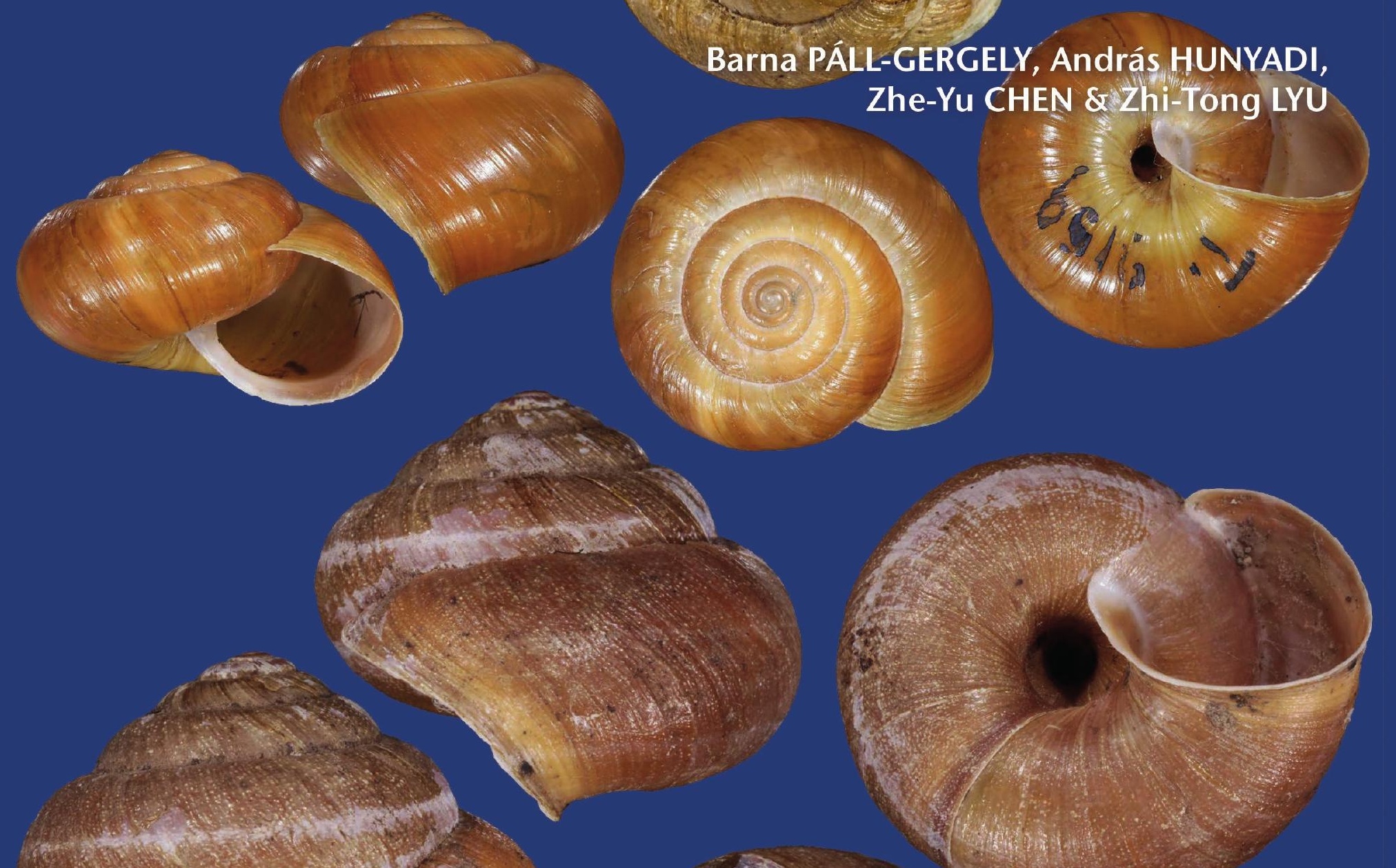


DiRECTEUR DE LA PUBLICATION: Bruno David

Président du Muséum national d'Histoire naturelle

\section{RÉDACTRICE EN CHEF / EDITOR-IN-CHIEF: Laure Desutter-Grandcolas}

ASSISTANTS DE RÉDACTION / ASSISTANT EDITORS: Anne Mabille (zoosyst@mnhn.fr), Emmanuel Côtez

\section{Mise en PAge / PAge LAYOUt: Anne Mabille}

COMITÉ SCIENTIFIQUE / SCIENTIFIC BOARD:

James Carpenter (AMNH, New York, États-Unis)

Maria Marta Cigliano (Museo de La Plata, La Plata, Argentine)

Henrik Enghoff (NHMD, Copenhague, Danemark)

Rafael Marquez (CSIC, Madrid, Espagne)

Peter $\mathrm{Ng}$ (University of Singapore)

Norman I. Platnick (AMNH, New York, États-Unis)

Jean-Yves Rasplus (INRA, Montferrier-sur-Lez, France)

Jean-François Silvain (IRD, Gif-sur-Yvette, France)

Wanda M. Weiner (Polish Academy of Sciences, Cracovie, Pologne)

John Wenzel (The Ohio State University, Columbus, États-Unis)

COUVERTURE / COVER:

Potential members of the genus Coccoglypta Pilsbry, 1895.

Zoosystema est indexé dans / Zoosystema is indexed in:

- Science Citation Index Expanded (SciSearch ${ }^{\circledR}$ )

- ISI Alerting Services ${ }^{\circledR}$

- Current Contents ${ }^{\circledR} /$ Agriculture, Biology, and Environmental Sciences ${ }^{\circledR}$

- Scopus ${ }^{\circledR}$

Zoosystema est distribué en version électronique par / Zoosystema is distributed electronically by:

- BioOne ${ }^{\circledR}$ (http://www.bioone.org)

Les articles ainsi que les nouveautés nomenclaturales publiés dans Zoosystema sont référencés par / Articles and nomenclatural novelties published in Zoosystema are referenced by:

- ZooBank ${ }^{\circledR}$ (http://zoobank.org)

Zoosystema est une revue en flux continu publiée par les Publications scientifiques du Muséum, Paris / Zoosystema is a fast track journal published by the Museum Science Press, Paris

Les Publications scientifiques du Muséum publient aussi / The Museum Science Press also publish:

Adansonia, Geodiversitas, Anthropozoologica, European Journal of Taxonomy, Naturae, Cryptogamie sous-sections Algologie, Bryologie, Mycologie.

Diffusion - Publications scientifiques Muséum national d'Histoire naturelle

CP $41-57$ rue Cuvier F-75231 Paris cedex 05 (France)

Tél.: 33 (0)1 40794805 / Fax: 33 (0)1 40793840

diff.pub@mnhn.fr / http://sciencepress.mnhn.fr

(C) Publications scientifiques du Muséum national d'Histoire naturelle, Paris, 2019

ISSN (imprimé / print): 1280-9551/ ISSN (électronique / electronic): 1638-9387 


\title{
A review of the genus Coccoglypta Pilsbry, 1895 (Gastropoda: Pulmonata: Camaenidae)
}

\author{
Barna PÁLL-GERGELY \\ Plant Protection Institute, Centre for Agricultural Research, \\ Herman Ottó Street 15, Budapest, H-1022 (Hungary) \\ pall-gergely.barna@agrar.mta.hu \\ pallgergely2@gmail.com (corresponding author)
}

András HUNYADI

Adria sétány 10G 2/5., Budapest H-1148 (Hungary)

Zhe-Yu CHEN

Changqing Campus, College of food science and engineering, Wuhan Polytechnic University, Wuhan 430023, (P.R. China)

Zhi-Tong LYU

The Museum of Biology, School of Life Sciences, Sun Yat-sen University, Guangzhou 510275, (P.R. China)

Submitted on 4 January 2019 | Accepted on 8 April 2019 | Published on 20 December 2019

KEY WORDS

Anatomy,

shell sculpture,

China,

new combinations, new species.
urn:Isid:zoobank.org:pub:D8049201-7F49-48A9-BA4D-5D6AEC55430E

Páll-Gergely B., Hunyadi A., Chen Z.-Y. \& Lyu Z.-T. 2019. - A review of the genus Coccoglypta Pilsbry, 1895 (Gastropoda: Pulmonata: Camaenidae). Zoosystema 41 (29): 595-608. https://doi.org/10.5252/zoosystema2019v41a29. http://zoosystema.com/41/29

\section{ABSTRACT}

So far, the genus Coccoglypta Pilsbry, 1895 consisted of two species and two subspecies as follows: C. pinchoniana (Heude, 1886) type species of the genus, C. scrobiculata scrobiculata (Gredler, 1885) and C. scrobiculata hupeiana (Gredler, 1887). We examined shells and genitalia, and performed molecular analyses of Coccoglypta specimens from Sichuan Province, which have revealed the existence of a yet undescribed species (Coccoglypta liui Páll-Gergely, n. sp.). Based on conchological information, Coccoglypta scrobiculata does not belong to the Camaenidae Pilsbry, 1895 s.l., but to the Ariophantidae Godwin-Austen, 1883. Since the systematics of Ariophantidae is not fully resolved yet, it is difficult to place this species in an appropriate genus. The conchologically most similar species is Hemiplecta laotica (Möllendorff, 1899), therefore Coccoglypta scrobiculata is transferred to the genus Hemiplecta Albers, 1850. Eulota arbusticola chrysomphala Möllendorff, 1899 is elevated to species level, and treated as "Bradybaena" chrysomphala (Möllendorff, 1899), because its shell differs considerably from that of Bradybaena arbusticola (Deshayes, 1870). Bradybaena arbusticola, Satsuma leprosula (Heude, 1885) and Helix billiana Heude, 1882 are assigned to Coccoglypta based on their mamillated sculpture. 


\author{
MOTS CLÉS \\ Anatomie, \\ coquille sculpture, \\ combinaisons nouvelles, \\ espèce nouvelle.
}

\begin{abstract}
RÉSUMÉ
Étude sur le genre Coccoglypta Pilsbry, 1895 (Gastropoda: Pulmonata: Camaenidae).

Jusqu’à présent, le genre Coccoglypta Pilsbry, 1895 comprenait deux espèces et deux sous-espèces : C. pinchoniana (Heude, 1886) espèce type du genre, C. scrobiculata scrobiculata (Gredler, 1885) et C. scrobiculata hupeiana (Gredler, 1887). Nous avons examiné les coquilles et les genitalia et effectué des analyses moléculaires des spécimens de Coccoglypta de la province du Sichuan, qui ont révélé l'existence d'une espèce encore non décrite (Coccoglypta liui Páll-Gergely, n. sp.). Sur la base d'informations conchologiques, Coccoglypta scrobiculata n'appartient pas aux Camaenidae Pilsbry, 1895 s.l., mais aux Ariophantidae Godwin-Austen, 1883. La systématique des Ariophantidae n'étant pas encore entièrement résolue, il est difficile de placer cette espèce dans le genre approprié. Du point de vue des caractères conchologiques, l'espèce la plus similaire étant Hemiplecta laotica (Möllendorff, 1899), Coccoglypta scrobiculata est donc transférée au genre Hemiplecta Albers, 1850. Eulota arbusticola chrysomphala Möllendorff, 1899 est élevée au niveau espèce et traitée comme "Bradybaena" chrysomphala (Möllendorff, 1899), car sa coquille differe considérablement de celle de Bradybaena arbusticola (Deshayes, 1870). Bradybaena arbusticola, Satsuma leprosula (Heude, 1885 ) et Helix billiana Heude, 1882 sont affectés à Coccoglypta sur la base de leur sculpture mamillée.
\end{abstract}

\section{INTRODUCTION}

So far, Coccoglypta Pilsbry, 1895 has been known as a group of middle-sized camaenids inhabiting China (Schileyko 2004). Yen (1939) recognised two species and two subspecies as members of this genus: C. pinchoniana (Heude, 1886) from Sichuan, C. scrobiculata scrobiculata (Gredler, 1885) from Hunan and C. scrobiculata hupeiana (Gredler, 1887) from Hubei.

We have examined shell and ethanol-preserved material of Coccoglypta from Qingcheng Shan and Qingcheng Houshan (Near Chengdu, Sichuan), which resulted in the recognition of two distinct species, one being C. pinchoniana, and the other being a species new to science. Examining shells of Coccoglypta species and those of $C$. scrobiculata also revealed that the latter species does not belong to the Camaenidae Pilsbry, 1895, but probably to the Ariophantidae Godwin-Austen, 1883, although its generic placement is challenging due to the poorly established classification of that family. Some camaenids are known from the geographic vicinity of the area of Coccoglypta that share the finely mamillated teleoconch sculpture of that genus. However, without knowing the reproductive anatomy we can only hypothesise that they are related to Coccoglypta.

The paper of Wu \& Liu (2019) (published on 6 August 2019) transferred Zonites scrobiculatus Gredler, 1885 to the newly described Sinoxychilus Wu \& Liu, 2019. The present manuscript was accepted on 8 April 2019 and published on 20 December 2019, and classifies that species in Hemiplecta Albers, 1850. Instead of rewriting our manuscript entirely, we decided to publish the accepted version, which was written without knowing the results of Wu \& Liu (2019).

\section{MATERIAL AND METHODS}

Shell whorls $( \pm 0.25)$ were counted according to Kerney \& Cameron (1979: 13). Shells were measured using a vernier caliper. Ethanol-preserved specimens were dissected under a Leica stereo microscope with a camera attached to provide photographs of the external genital structure, from which drawings were produced. Appendix 1 presents locality names cited verbatim from the specimen labels.

\section{MOLECULAR ANALYSIS}

Muscle tissue for DNA extraction was attained from each a specimen of Coccoglypta liui Páll-Gergely, n. sp. (A1, China, Sichuan Province, Qingcheng Houshan, c. 30 $0^{\circ} 55^{\prime} \mathrm{N}, 103^{\circ} 29^{\prime} 40^{\prime} \mathrm{E}$, Liu Zheng-Ping leg. , 07.IV.2018, SYS m001013) and Coccoglypta pinchoniana (China, Sichuan Province, Chongzhou Shi, Jiezi Zhen, Fengqishan [风栖山], Liu Zheng-Ping leg., 13.I.2018, SYS $\mathrm{m} 001014$ ), and then preserved in 95\% ethanol. Genomic DNA was extracted from muscular tissue by using a DNA extraction kit from Tiangen Biotech (Beijing) Co., Ltd. Two mitochondrial genes, partial $16 S$ ribosomal RNA gene (16S) and partial cytochrome $C$ oxidase 1 gene (CO1), were amplified. Primers used for $16 S$ were 16SA (5'-CGGCCGCCTGTTTATCAAAAACAT-3') and 16SB (5'-GGAGCTCCGGTTTGAACTCAGATC-3'), and for CO1 were co1F (5'-GGTCAACAAATCATAAAGATATTGG-3') and co1R (5'-TTAACTTCAGGGTGACCAAAAAATCA-3'). PCR amplifications were processed in a $20 \mu \mathrm{l}$ reaction volume with the cycling conditions of an initial denaturing step at $94^{\circ} \mathrm{C}$ for $2 \mathrm{~min}$, 35 cycles of denaturing at $94^{\circ} \mathrm{C}$ for $30 \mathrm{~s}$, annealing at $50^{\circ} \mathrm{C}$ for 30 $s$ and extending at $72^{\circ} \mathrm{C}$ for 30 s, and final extending step of $72^{\circ} \mathrm{C}$ for $10 \mathrm{~min}$. PCR products were purified with spin columns. The purified products were sequenced by Beijing Genomics Institute. All sequences were deposited in GenBank (Table 1). In addition, 59 sequences from 36 known camaenid species were obtained from GenBank and incorporated into our dataset (Table 1).

DNA sequences of the two genes were aligned respectively by the Clustal W algorithm with default parameters (Thompson et al. 1997) in MEGA 6 (Tamura et al. 2013). The alignments were trimmed with allowing no gap positions and default parameters in Gblocks version 0.91b (Castresana 2000). The two genes, 402 base pairs (bp) of $16 \mathrm{~S}$ and 655 bp of CO1, were concatenated into a 1068-bp sequence, which was further tested in jmodeltest v2.1.2 with Akaike and Bayesian information criteria, resulting in the best-fitting nucleotide substitution model of GTR + I + G. Sequenced data were analysed using Bayesian inference (BI) in MrBayes 3.2.4 (Ron- 
quist et al. 2012). Three independent runs were conducted, each of which was performed for 8000000 generations and sampled every 1000 generations with the first 25\% samples discarded as burn-in. Convergence of the Markov Chain Monte Carlo simulations was assessed using Tracer v1.5 (Rambaut \& Drummond 2009), verifying that all ESS values exceeded 200. P-distance between taxa was calculated using MEGA 6.

\section{ABBREVIATIONS}

Private collection

Coll. HA collection András Hunyadi, Budapest.

\section{Institutions}

HBUMM Mollusc collection of the Museum of Hebei University, Baoding;

HNHM Hungarian Natural History Museum, Budapest;

MNHN Muséum national d'Histoire naturelle, Paris;

MCZ Museum of Comparative Zoology, Massachusetts;

SMF Senckenberg Forschungsinstitut und Naturmuseum, Frankfurt am Main;

SYS The Museum of Biology, Sun Yat-sen University, Guangzhou;

UMZC University Museum of Zoology, Cambridge;

USNM Smithsonian National Museum of Natural History, Washington.

\section{RESULTS}

The two Coccoglypta species form a clade with $100 \%$ posterior probability. No close relative was revealed by the phylogram, which is likely due to the limited sequences of this family deposited to GenBank. The two Coccoglypta species are separated by the genetic distances at $4.0 \%$ in the $16 \mathrm{~S}$ gene and $10.6 \%$ in the COI.

Although their anatomy is unknown, based on the mamillated sculpture and geographic proximity, three species, namely Helix arbusticola Deshayes, 1870, Helix billiana Heude, 1882 and Helix leprosa Heude, 1885 are moved to Coccoglypta. However, we note that future revision of their evolutionary relationships based on genital anatomy and molecular phylogeny is necessary.

\section{TAXONOMIC DESCRIPTIONS}

$$
\text { Family Camaenidae Pilsbry, } 1895
$$

\section{Subfamily Bradybaeninae Pilsbry, 1934}

\section{REMARKS}

Camaenidae and Bradybaenidae Pilsbry, 1934 are traditionally distinguished on the basis of the absence of the dart sac and mucous glands in the former and their presence in latter. The molecular phylogeny of Wade et al. $(2006,2007)$ showed that the dart sac was lost multiple times during the evolution of the Camaenidae. Camaenidae and Bradybaenidae form a single clade, but neither of them is monophyletic. Therefore Gittenberger et al. (2012) formally treated the Bradybaenidae as a junior synonym of Camaenidae. Bouchet et al. (2017) retained the subfamily Bradybaeninae Pilsbry, 1934 under Camaenidae. This system is followed here.
TABLE 1. - Samples and the GenBank ID used in this study.

\begin{tabular}{|c|c|c|c|}
\hline \multirow[b]{2}{*}{ ID } & \multirow[b]{2}{*}{ Species } & \multicolumn{2}{|c|}{ GenBank ID } \\
\hline & & $16 S$ & CO1 \\
\hline 1 & Coccoglypta liui Páll-Gergely, n. sp. & MK680922 & MK680001 \\
\hline 2 & Coccoglypta pinchoniana (Heude, 1886) & MK680923 & MK680002 \\
\hline 3 & Acusta despecta (Sowerby I, 1839) & LC168907 & LC168926 \\
\hline 4 & $\begin{array}{l}\text { Aegista diversifamilia Huang, Lee, Lin \& } \\
\text { Wu, } 2014\end{array}$ & KJ574303 & KJ574343 \\
\hline 5 & Aegista mackensii (Adams \& Reeve, 1850) & KJ574327 & KJ574369 \\
\hline 6 & Aegista subchinensis (Möllendorff, 1884) & KJ574321 & KJ574361 \\
\hline 7 & Ainohelix editha (A. Adams, 1868) & AB893656 & LC168943 \\
\hline 8 & Amphidromus adamsii (Reeve, 1848) & AB112370 & - \\
\hline 9 & Amphidromus perversus (Linnaeus, 1758) & AB112375 & - \\
\hline 10 & Amphidromus semitessellatus (Morlet, 1885) & AB112379 & - \\
\hline 11 & Amplirhagada burnerensis (E. A. Smith, 1894) & HQ245372 & KC703098 \\
\hline 12 & Basedowena elfina (Iredale, 1939) & KU519216 & KU519137 \\
\hline 13 & Bradybaena phaeogramma (Ancey, 1888) & AF098714 & - \\
\hline 14 & Bradybaena sequiniana (Heude, 1885) & KU586458 & KU586501 \\
\hline 15 & Bradybaen & HQ245444 & - \\
\hline 16 & a cicatricosa (O. F. Müller, 1774) & KU586474 & KU061276 \\
\hline 17 & Camaena poyuensis Zhou, Wang \& Ding, 2016 & 468 & KU061273 \\
\hline 18 & Dolicheulota formosensis (H. Adams, 1866) & KR338956 & KR338956 \\
\hline 19 & Euhadra amaliae (Kobelt, 1875) & AF279274 & - \\
\hline 20 & peliomphala (L. Pfeiffer, 1850) & AF104052 & - \\
\hline 21 & Euhadra quaesita ( & AF2 & - \\
\hline 22 & Euhadra scaevola (Martens, 1877) & AF279273 & - \\
\hline 23 & $\begin{array}{l}\text { Exiligada gregoriana Criscione, Law \& } \\
\text { Köhler, } 2012\end{array}$ & JX393672 & JX393761 \\
\hline 24 & Ezohelix gainesi (Pilsbry, 1900) & AB893736 & LC168941 \\
\hline 25 & Falspleuroxia overlandensis Solem, 1997 & KU519178 & KU519261 \\
\hline 26 & Mandarina anijimana Chiba, 1996 & AY829598 & - \\
\hline 27 & Mandarina a & AF095823 & - \\
\hline 28 & Mandarina hirasei Pilsbry, 1902 & AF098693 & - \\
\hline 29 & Mandarina mandarina (Sowerby I, 1839) & AY829604 & - \\
\hline 30 & Mastigeulota kiangsinensis (Martens, 1875) & KM083123 & KM083123 \\
\hline 31 & Paraegista takahidei Kuroda \& Azuma, 1951 & LC168923 & LC168970 \\
\hline 32 & Satsuma formosensis (L. Pfeiffer, 1866) & EF204776 & EF204813 \\
\hline 33 & Satsuma phoenicis Wu, Hwang \& Lin, 2008 & EF057350 & EF057381 \\
\hline 34 & Satsuma succincta rubrotincta (Kuroda, 1941) & EF204804 & EF204841 \\
\hline 35 & Sinumelon vagente Iredale, 1939 & KJ189759 & KJ189748 \\
\hline 36 & Tatemelon musgum (Iredale, 1937) & KU519194 & KU519277 \\
\hline 37 & Cornu aspersum (O. F. Müller, 1774) & KU586459 & KU586502 \\
\hline
\end{tabular}

\section{Genus Coccoglypta Pilsbry, 1895}

Eulota (Coccoglypta) Pilsbry, 1895: 211.

Coccoglypta - Yen 1939: 153. — Schileyko 2004: 1678-1679, fig. 2164.

TyPe SPECIES. - Helix pinchoniana Heude, 1886, by monotypy.

Diagnosis. - Shell dextral, depressed-conical, with 5-6 slightly convex whorls; body whorl rounded or slightly keeled; colour yellowish to greenish and light brown; protoconch without notable sculpture, seemingly smooth, or slightly pitted or "hammered"; teleoconch with irregular, rough wrinkles and strong tubercles, occasionally with fine spiral grooves; sculpture on ventral surface sometimes weaker than on dorsal side; aperture rounded to suboval, strongly oblique to shell axis; peristome expanded but not reflected; parietal callus weak, only indicated by fine whitish calcareous layer; umbilicus open, moderately wide to rather narrow, shows all whorls. Penis cylindrical or flattened, moderately long, internally with fine longitudinal pilasters or reticulated sculpture; no epiphallus observed; vas deferens slender, retractor muscle attached on the junction of penis and vas deferens; vagina short, internally with widely-spaced, sometimes converging longitudinal folds; stylophore of moderate size, accessory sac of about same size and shape, each of two alveolar; mucus glands large, distinct or forming a single gland mass, entering accessory sac independently; spermathecal stalk extremely long, bursa oval, small. 


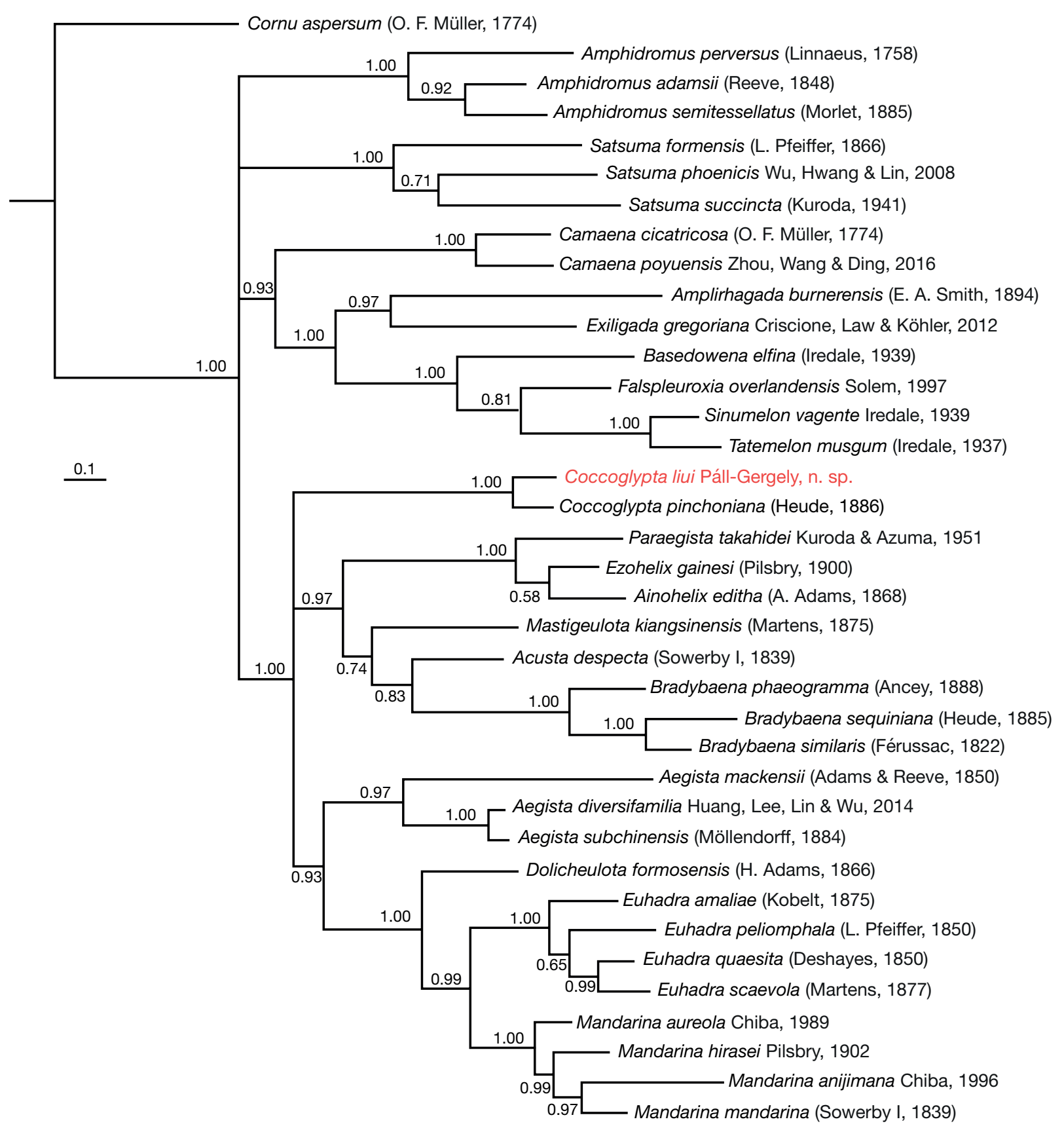

FIG. 1. - Phylogenetic tree using Bayesian inference with mitochondrial $16 \mathrm{~S}$ and $\mathrm{CO} 1$ genes. Numbers above or below branches indicate Bayesian posterior probabilities.

\section{REMARKS}

Coccoglypta was erected as a section of Eulota W. Hartmann, 1841 for two species, namely "Helix dimidiata Heude" and "Helix pinchoniana Heude". Pilsbry (1895) designated the former species as the type species. Heude, however, has never described a species with the name dimidiata (see Johnson 1973). Yen (1939) and Zilch (1959-1960) corrected this mistake and clarified type species of Coccoglypta as Helix pinchoniana Heude, 1886.
Coccoglypta liui Páll-Gergely, n. sp.

(Figs 2A-D; 3, 4)

urn:Isid:zoobank.org:act:8944C8EA-ECB5-4A77-B514-7A35ACE26945

TyPe MATERIAL. - Holotype. China, Sichuan, Chengdu Shi, Dujiangyan Shi, Qingcheng Houshan; 1200 m a.s.l.; Okubo leg.; 27.X.2014; HNHM 103475; D = 32.9 mm, H = 20.6 mm (Fig. 2A-D).

Paratypes. 2015/50; China, Sichuan, Chengdu Shi, Dujiangyan Shi, Qingcheng Shan, Buyun Cableway upper station - Shangqing- 


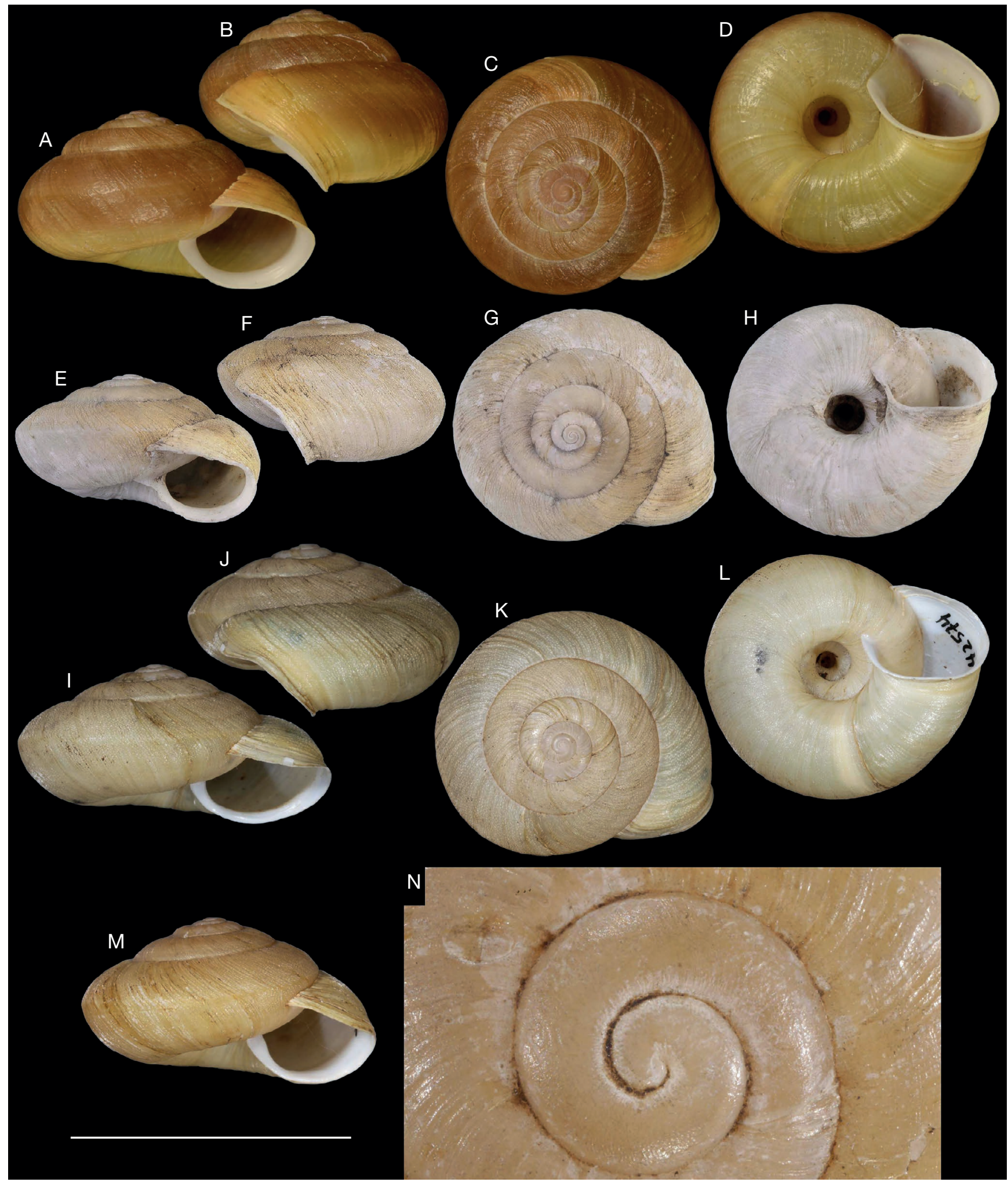

FIG. 2. - Shells of Coccoglypta Pilsbry, 1895 species: A-D, Coccoglypta liui Páll-Gergely, n. sp. (holotype); E-F, syntype of Coccoglypta pinchoniana (USNM 472156); I-L, Coccoglypta cf. pinchoniana from Emei Shan (SMF 42574); M, second specimen of Coccoglypta cf. pinchoniana from the same sample as previous; $\mathbf{N}$, protoconch of the same shell as I-L. Scale bar: $30 \mathrm{~mm}$; N, not to scale.

gong; 1150 m a.s.l.; $30^{\circ} 54.783^{\prime} \mathrm{N}, 103^{\circ} 33.714^{\prime} \mathrm{E}$; A. Hunyadi leg.; 06.VI.2015; coll. HA/1 paratype. — 2015/45; Sichuan, Chengdu Shi, Dujiangyan Shi, Qingcheng Houshan, Taian Zhen, Baiyun Cun, Jiusengdong; $1530 \mathrm{~m}$ a.s.l.; $30^{\circ} 56.786^{\prime} \mathrm{N}, 103^{\circ} 28.587^{\prime} \mathrm{E} ; \mathrm{A}$.
Hunyadi leg.; 04.VI.2015; coll. HA/1 adult paratype. - A1; China, Sichuan Province, Qingcheng Houshan; c. 30 $55^{\prime} \mathrm{N}, 103^{\circ} 29^{\prime} 40^{\prime \prime} \mathrm{E}$ Liu Zheng-Ping leg.; 07.IV.2018; SYS m001013 (paratype used for molecular study). — Qingcheng Houshan, Shuijing Dong 


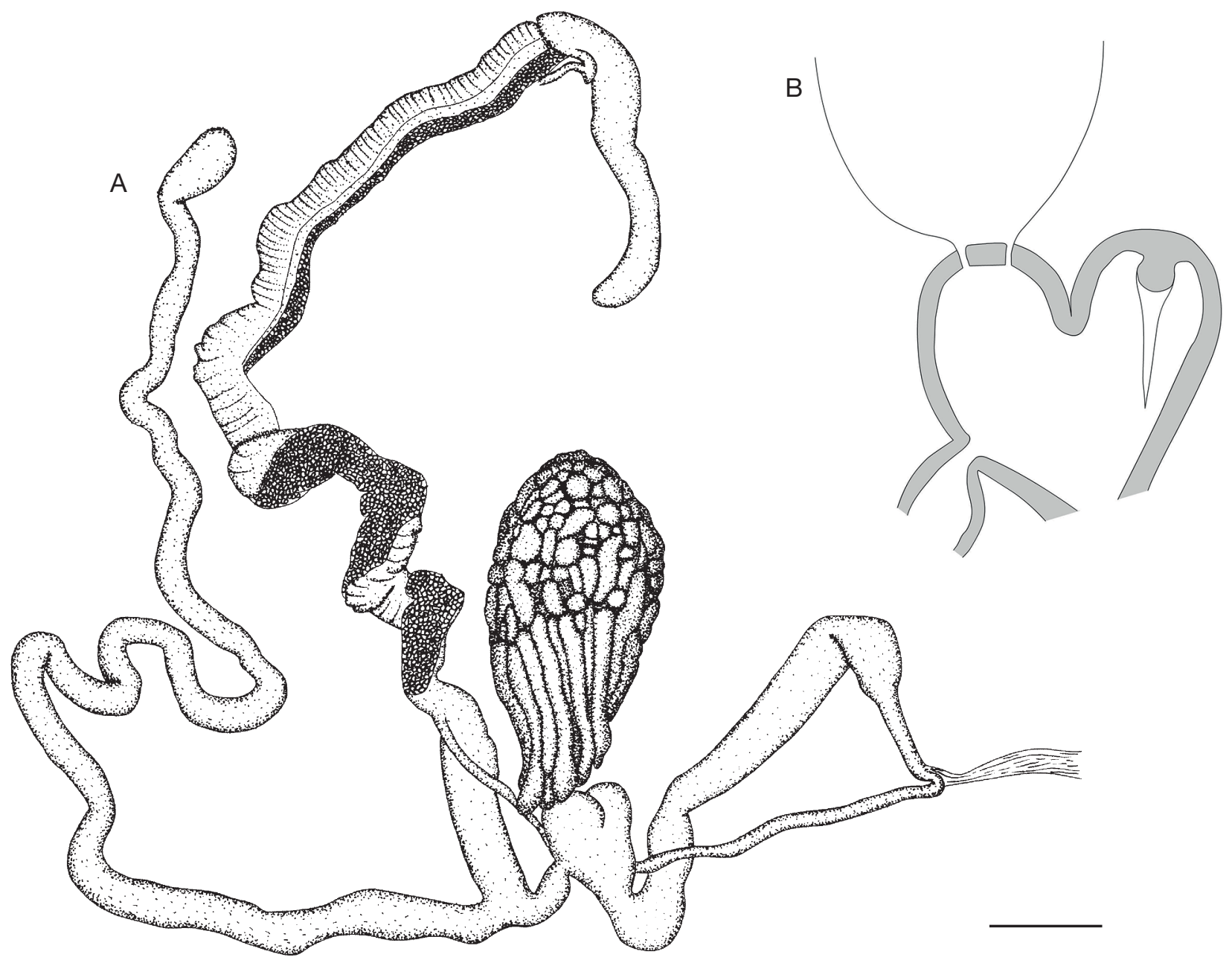

FIG. 3. - Reproductive anatomy of Coccoglypta liui Páll-Gergely, n. sp. (holotype, HNHM 103475): A, entire genitalia; B, schematic drawing of the inner structure of the dart sac. Scale bar: A, $5 \mathrm{~mm}$.

[水晶洞], 2016; Liu Zheng-Ping leg.; HBUMM10005; empty shell.

OTHER MATERIAL EXAMINED. — 2015/50; China, Sichuan, Chengdu Shi, Dujiangyan Shi, Qingcheng Shan, Buyun Cableway upper station - Shangqinggong; $1150 \mathrm{~m}$ a.s.l.; $30^{\circ} 54.783^{\prime} \mathrm{N}, 103^{\circ} 33.714^{\prime} \mathrm{E}$; A. Hunyadi leg.; 06.VI.2015; coll. HA/ 7 juvenile/broken shells. - 2015/45; Sichuan, Chengdu Shi, Dujiangyan Shi, Qingcheng Houshan, Taian Zhen, Baiyun Cun, Jiusengdong; $1530 \mathrm{~m}$ a.s.l.; $30^{\circ} 56.786^{\prime} \mathrm{N}, 103^{\circ} 28.587^{\prime} \mathrm{E}$; A. Hunyadi leg.; 04.VI.2015; coll. HA/ 2 juveniles.

Etymology. - This new species is named after Liu Zheng-Ping, who has made important contributions to the discovery of this new species.

TyPe LOCALITY. - China, Sichuan, Chengdu Shi, Dujiangyan Shi, Qingcheng Houshan, $1200 \mathrm{~m}$ a.s.l.

DiAgnOSIS. - A Coccoglypta species with a rounded body whorl, greenish to yellowish colour and weak sculpture on the ventral shell surface.

\section{DESCRIPTION}

Shell dextral, rather large, light brown (dorsal surface) to greenish or yellowish (ventral surface, and dorsal side behind the aperture); colour changing below keel, and some light colouration indicating some growth lines; shell depressed globular, body whorl rounded or with very slightly marked keel (if present, mostly visible from ventral view of the body whorl); entire shell consisting of 5.25-5.75 whorls, separated by rather shallow suture, sometimes indicated by a whitish line; protoconch consisting of 1.5-1.75 whorls, matt, rather smooth, dorsal side of teleoconch dominated by irregular, rather rough wrinkles and tubercles (tubercles appearing after the first 1.5 whorls of teleoconch); some fine spiral grooves also visible; ventral surface without or with much less prominent tubercles, rather "hammered", irregularly wrinkled and spirally grooved; aperture strongly oblique to shell axis, white; peristome expanded (mostly in basal and umbilical direction) but not reflected; parietal callus weak, only indicated by fine whitish calcareous layer, which is transparent in fresh shells; umbilicus open, moderately wide, showing all whorls.

\section{Measurements}

$\mathrm{D}=29.1-32.9 \mathrm{~mm}, \mathrm{H}=16.1-20.6 \mathrm{~mm}(\mathrm{n}=3)$. 


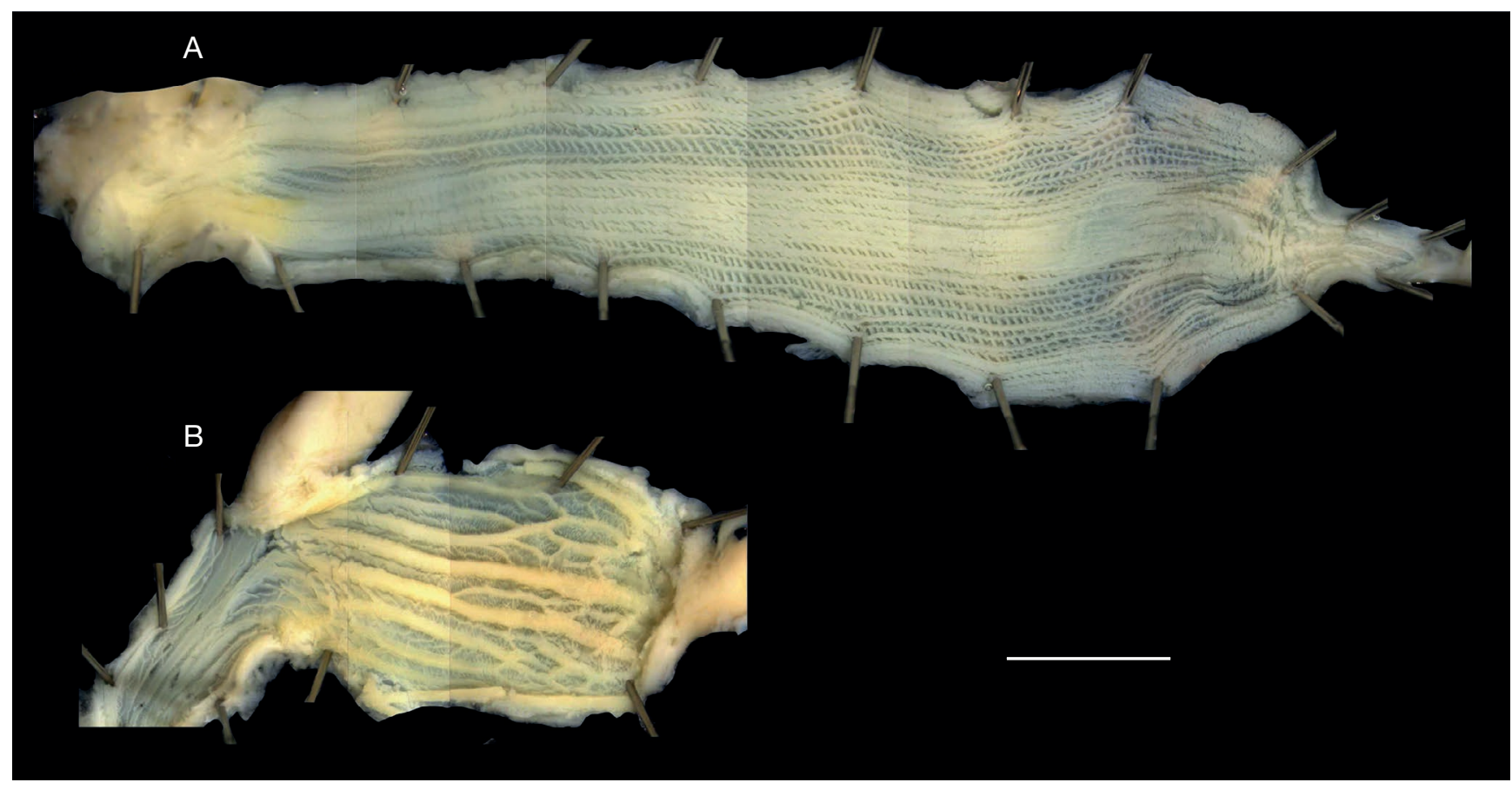

FIG. 4. - Inner structure of the genitalia of Coccoglypta liui Páll-Gergely, n. sp. (holotype, HNHM 103475): A, penis; B, vagina. Genital atrium situated leftwards in both images. Scale bar: $5 \mathrm{~mm}$.

\section{Remarks on the genitalia}

From a single specimen anatomically examined from Qingcheng Houshan (Figs 3-4). Right ommatophoral retractor crossed vagina and penis. Inner wall of the penis finely reticulated (Fig. 4A), produced by the perpendicular projections of the slender longitudinal folds. Inner wall of vagina with widelyspaced, sometimes converging longitudinal folds (Fig. 4B).

DifFerential Diagnosis. - Coccoglypta liui Páll-Gergely, n. sp. differs from C. pinchoniana, which also occurs sympatrically, by the usually narrower umbilicus, weaker sculpture of the ventral surface, the lighter colour, and the less keeled body whorl. The ventral side of $C$. pinchoniana is dominated by ribs and tubercles, but also has fine spiral grooves. However, the ventral shell surface of Coccoglypta liui Páll-Gergely, n. sp. has much less prominent tubercles and is dominated by spiral grooves.

DisTRIBUTION . - So far this species is known only from Qingcheng Houshan and Qingcheng Shan in Sichuan Province, China (Fig. 5).

\section{REMARKS}

Our observations on the genitalia generally match with those of Schileyko (2004), based on a C. pinchoniana specimen collected in Emei Shan. The notable differences are the following: 1) the mucus glands form a single oval mass, not separated clearly as on Schileyko's (2004) drawing; 2) we have not found a twisted part of the spermathecal stalk in a capsule; and 3) the bursa copulatrix is smaller and more elongated than the specimen examined by Schileyko (2004). It is yet unclear which of these differences represents speciesspecific traits.
Coccoglypta pinchoniana (Heude, 1886)

(Fig. 2E-N)

Helix pinchoniana Heude, 1886: 213.

Coccoglypta pinchoniana - Yen 1936: 335-336; 1939: 153, pl. 15, fig. 64. - Zilch 1960: 640-641, fig. 2242. - Chen \& Gao 1987: 158-159, fig. 204. — Schileyko 2004: 1678-1679, fig. 2164. Chen \& Zhang 2004: 371-372, fig. 370.

Type Material eXamined. - Syntypes. USNM 472156 and MCZ 167190.

Additional material eXAmined. - "Berg Omi, Sytchuan"; Schmacker leg. 1893; SMF 42574/2. — 2015/50; China, Sichuan, Chengdu Shi, Dujiangyan Shi, Qingcheng Shan, Buyun Cableway felső állomás - Shangqinggong; $1150 \mathrm{~m}$ a.s.l.; $30^{\circ} 54.783^{\prime} \mathrm{N}$, 103⒊714'E; A. Hunyadi leg.; 06.VI.2015, coll. HA/1. — 2015/51a; China, Sichuan, Chengdu Shi, Dujiangyan Shi, Qingcheng Shan, Chaoyangdong $50 \mathrm{~m}$ towards Shangqinggong; A. Hunyadi leg.; 06.VI.2015; coll. HA/2. - 2015/55; China, Sichuan, Chengdu Shi, Dujiangyan Shi, Qingcheng Shan, Jinbian Yan; 940 m a.s.l.; $30^{\circ} 53.733^{\prime} \mathrm{N}, 103^{\circ} 33.087^{\prime} \mathrm{E}$; A. Hunyadi leg.; 07.VI.2015; coll. HA/1. - China, Sichuan Province, Chongzhou Shi, Jiezi Zhen, Fengqishan; Liu Zheng-Ping leg.; 13.I.2018; SYS m001014 (specimen used for molecular study).

TYPE LOCALITY. — Tchen-tou-fou (Chengdu city, Sichuan Province).

DiaGNOSIS. - A Coccoglypta species with a keeled body whorl, light brown, greenish to greyish colour and strong sculpture on the ventral shell surface.

Distribution. - This species is more widely distributed than C. liui Páll-Gergely, n. sp. Namely, it was collected on the Emei Shan, the Qingcheng Shan and Fengqishan. 


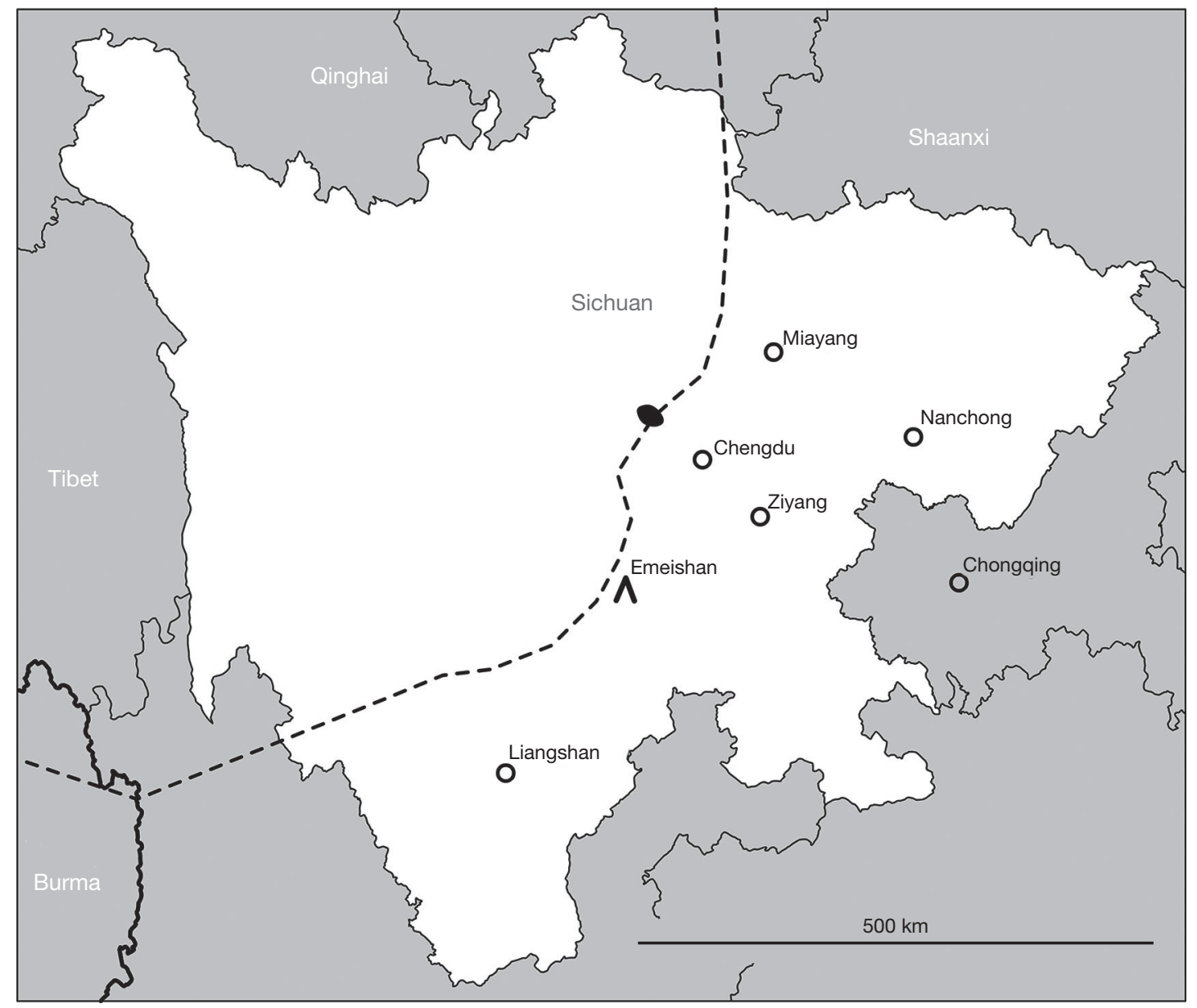

FIG. 5. - Map of Sichuan showing the localities of Coccoglypta Pilsbry, 1895 species. Dashed line shows the edge of the Tibetan Plateau. Coccoglypta pinchoniana (Heude, 1886) was described from Chengdu, and it was known from the Emeishan, and a fossil record from Chongqing. Now we report this species and C. liui Páll-Gergely, n. sp. from Qingcheng Shan and Qingcheng Houshan (black area).

\section{COMPLEMENT OF DESCRIPTION}

Shell dextral, rather large, light brown, greenish to greyish, dorsal and ventral surface of similar colour; shell depressed globular or conical, body whorl slightly or prominently keeled; entire shell consists of 5.25-5.75 whorls, separated by rather shallow suture; protoconch consisting of 1.5-1.75 whorls, matt, rather smooth, dorsal side of teleoconch dominated by irregular, very rough wrinkles and strong tubercles (tubercles appearing after the first 1.5 whorls of teleoconch); some fine spiral grooves also visible, especially close to the suture; ventral surface similar to dorsal, although with slightly weaker sculpture; aperture strongly oblique to shell axis, white; peristome expanded (mostly in basal and umbilical direction) but not reflected; parietal callus weak, only indicated by fine whitish calcareous layer, which is transparent in fresh shells; umbilicus open, moderately wide to rather narrow, showing all whorls.

\section{Measurements}

$\mathrm{D}=25.7-31.9 \mathrm{~mm}, \mathrm{H}=15 \cdot 0-17.5 \mathrm{~mm}(\mathrm{n}=6)$.

\section{REMARKS}

This species was originally described from Chengdu city, Sichuan Province (Heude, 1886). It is known as a subfossil record from Chongqing town (Yen 1936). This species is considered a vulnerable species (Wang \& Xie 2005).

Coccoglypta arbusticola (Deshayes, 1870) n. comb. (Fig. 6A-D)

Helix arbusticola Deshayes, 1870: 20.

non Bradybaena arbusticola arbusticola - Yen 1939: 135, pl. 14, fig. 2. non Coccoglypta arbusticola - Chen \& Zhang 2004: 155-156, fig. 123.

Type Material EXAMined. - China. Moupin [Muping Zhen, Sichuan], l'Abbé David, 1869, syntype, MNHN-IM-2000-34192.

Type LOCAlity. - "Principauté de Moupin, Thibet oriental" (from title). 


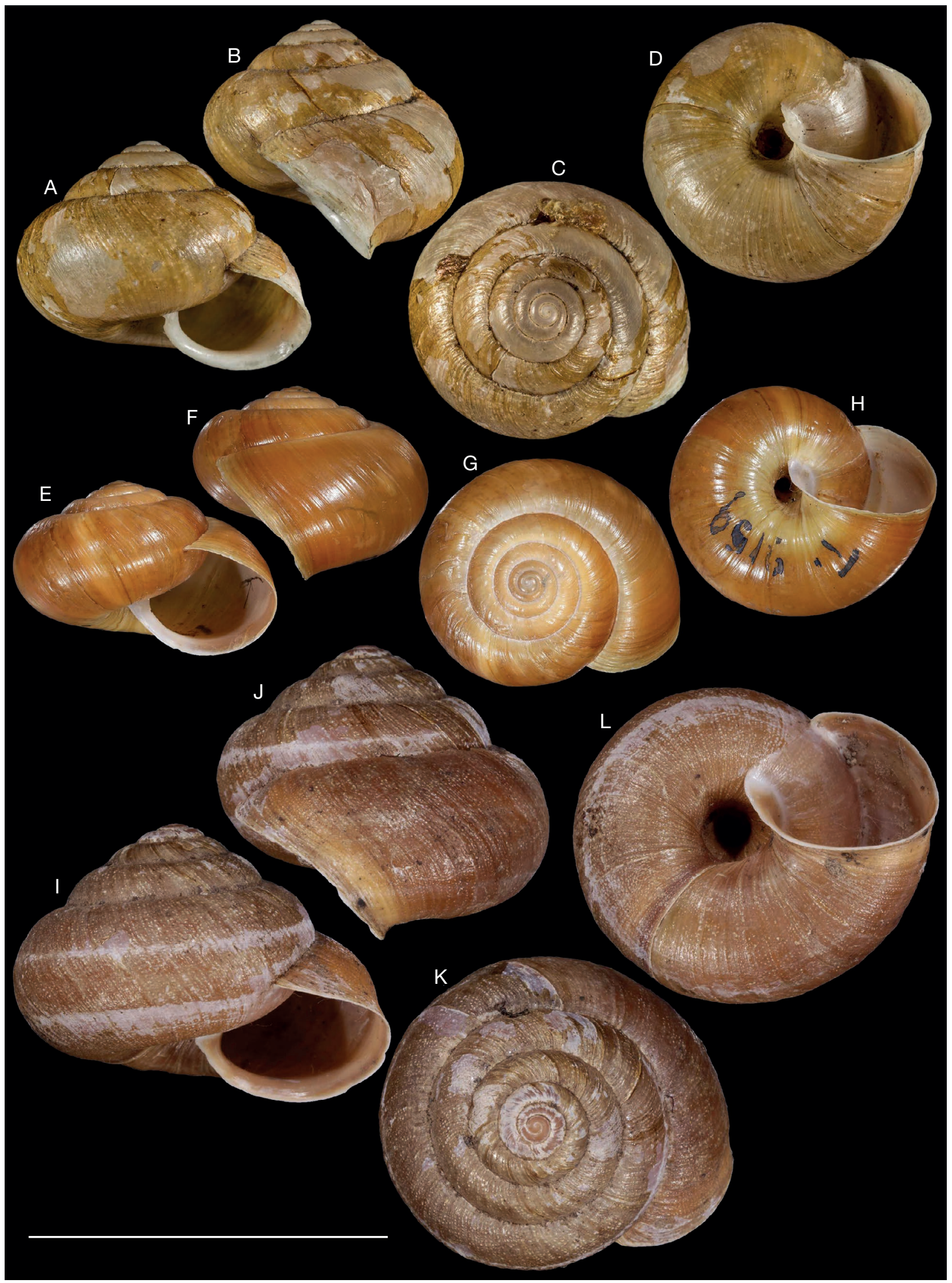

FIG. 6. - Potential members of the genus Coccoglypta Pilsbry, 1895: A-D, syntype of Coccoglypta arbusticola (Deshayes, 1870) n. comb. (MNHN-IM-2000-34192); E-H, "Bradybaena" chrysomphala (Möllendorff, 1899), SMF 9159 (lectotype); I-L, Coccoglypta cf. leprosula n. comb. (Heude, 1885) from the Guanwushan Forest Farm. Scale bar: $30 \mathrm{~mm}$. 


\section{REMARKS}

This species has previously been assigned to the genus Bradybaena, however it surely does not belong to that genus in its present concept. The type species of Bradybaena, $B$. similaris (Rang, 1831), has a small $(c .1 \mathrm{~cm})$, fragile shell without any distinctive sculpture. However, $C$. arbusticola $\mathrm{n}$. comb. is larger (shell diameter of syntype: $24.5 \mathrm{~mm}$ ), and has a thick, finely mamillated shell, reminiscent of those of Coccoglypta.

We have examined the lectotype of Eulota arbusticola chrysomphala Möllendorff, 1899 (see Möllendorff, 1899: 70 and Yen, 1939: 135) in the Senckenberg Museum (China: W. Sy-tshuan, Fu-bien-ho, SMF 9159, figs 6E-H). It had a light brown, very finely wrinkled and extremely finely spirally grooved shell, without any signs of mamillae. The aperture is also comparatively much larger in chrysomphala than in arbusticola. Thus, "Bradybaena" chrysomphala and Coccoglypta arbusticola n. comb. cannot be subspecies of the same species and must be considered as two distinct species.

The single shell in the Senckenberg Museum identified as B. arbusticola and figured by Yen (1939) has a narrower umbilicus and more rapidly growing whorls than the type, and there are also no signs of a mamillated sculpture. Therefore, we here exclude it from the present species. Its true identity remains unknown. Furthermore, the shell figured in Chen \& Zhang (2004) also belong to another species, because it has a narrower umbilicus, a dark spiral band, and a more strongly expanded peristome.

\section{Coccoglypta billiana (Heude, 1882) n. comb.}

Helix billiana Heude, 1882: 25, pl. 14, fig. 3.

TYPE LOCALITY. - "In montosis Kiun-tcheou, ditionis fluvii Han” (= in the mountain regions of Kiun-tcheou, the area of the Han River).

\section{REMARKS}

As for the previous species, Johnson (1973) did not mention type specimens in American museums, and we could not examine the types probably deposited in Beijing. Since the sculpture is also mamillated, the species also potentially belongs to Coccoglypta.

\section{Coccoglypta leprosula (Heude, 1885) n. comb. (Fig. 6I-L)}

Helix leprosa Heude, 1885a: 106, pl. 27, fig. 15.

Helix leprosula Heude, 1885b: 43.

Helix (Satsuma) leprosula - Tryon 1887: 220, pl. 51, figs 80-82.

Material eXamined. - China. Sichuan, Mianyang Shi, Jiangyou Shi, Wudu Zhen, Guanwushan Forest Farm; 31 ${ }^{\circ} 56^{\prime} 38.8^{\prime \prime N}$, 10444'1.1"E; 1590 m; A. Hunyadi \& M. Szekeres leg.; 21-22. VI.2015; coll. HA; 1 adult +2 juvenile shells (Coccoglypta cf. leprosula n. comb., Figures 6I-L).

TyPe LOCALITY. — “Tchen K’eou” (Chengkou, Chongqing Province).

\section{REMARKS}

Johnson (1973) did not mention type specimens in American museums, and we could not contact the Beijing Natural History Museum, where some of Heude's types are deposited. Therefore, we rely on the original description only. Accordingly, the shell is $26 \mathrm{~mm}$ wide, narrowly umbilicated, and the sculpture is finely tuberculated, as in Coccoglypta.

The specimen we examined matches the original description, but the identification is certainly doubtful. It was collected c. $370 \mathrm{~km}$ west from the type locality of "Satsuma" leprosula. However, it must be kept in mind that the type locality is just a rough estimate, Heude received specimens from other missionaries who collected shells during their travels across large geographic areas.

\section{Family ARIOPHANTIDAE Godwin-Austen, 1883}

\section{Genus Hemiplecta Albers, 1850}

TyPe SPECIES. - Helix humphreysiana I. Lea, 1841, by subsequent designation (Martens in Albers 1860).

\section{Hemiplecta (?) scrobiculata scrobiculata (Gredler, 1885)} (Fig. 7E-I)

Zonites scrobiculatus Gredler, 1885: 220-221, pl. 6, fig. 2. - Bachmann \& Gredler 1894: 416.

Coccoglypta scrobiculata scrobiculata - Yen 1939: 153, pl. 15, fig. 62.

Coccoglypta scrobiculata - Chen \& Zhang 2004: 370, fig. 368 (treating hupeina as a junior synonym).

Material examined. - China. Hunan, Heng-san-hsien, coll. O. v. Möllendorff, SMF 42575/3.

Type Locality. — "Hen-san, im Districte von Hen-kiou-fu in Hunan”.

\section{DESCRIPTION}

Shell dextral, medium-sized, dark yellowish-slightly greenish on both ventral and dorsal sides; shell depressed globularconical with a rounded body whorl; entire shell consisting of 4.75-5 whorls, separated by rather shallow suture; protoconch consisting of 1.75-2 whorls, very finely mamillated with recognisable spiral striation; dorsal side of teleoconch dominated by irregular, wavy ribs (waviness seemingly caused by spiral lines occurring only at back of ribs); area between middle line of body whorl (from apertural view) and ventral side (except for umbilicus region) glossy, with much weaker sculpture than on dorsal side or inside umbilicus; aperture oblique to shell axis, whitish in one specimen, but yellow in the other two; peristome not expanded; parietal callus weak, only indicated by fine whitish calcareous transparent layer; umbilicus open, rather narrow, deep, showing all whorls.

\section{Measurements}

$\mathrm{D}=18.4-19.9 \mathrm{~mm}, \mathrm{H}=10.7-12.0 \mathrm{~mm}(\mathrm{n}=3)$. 


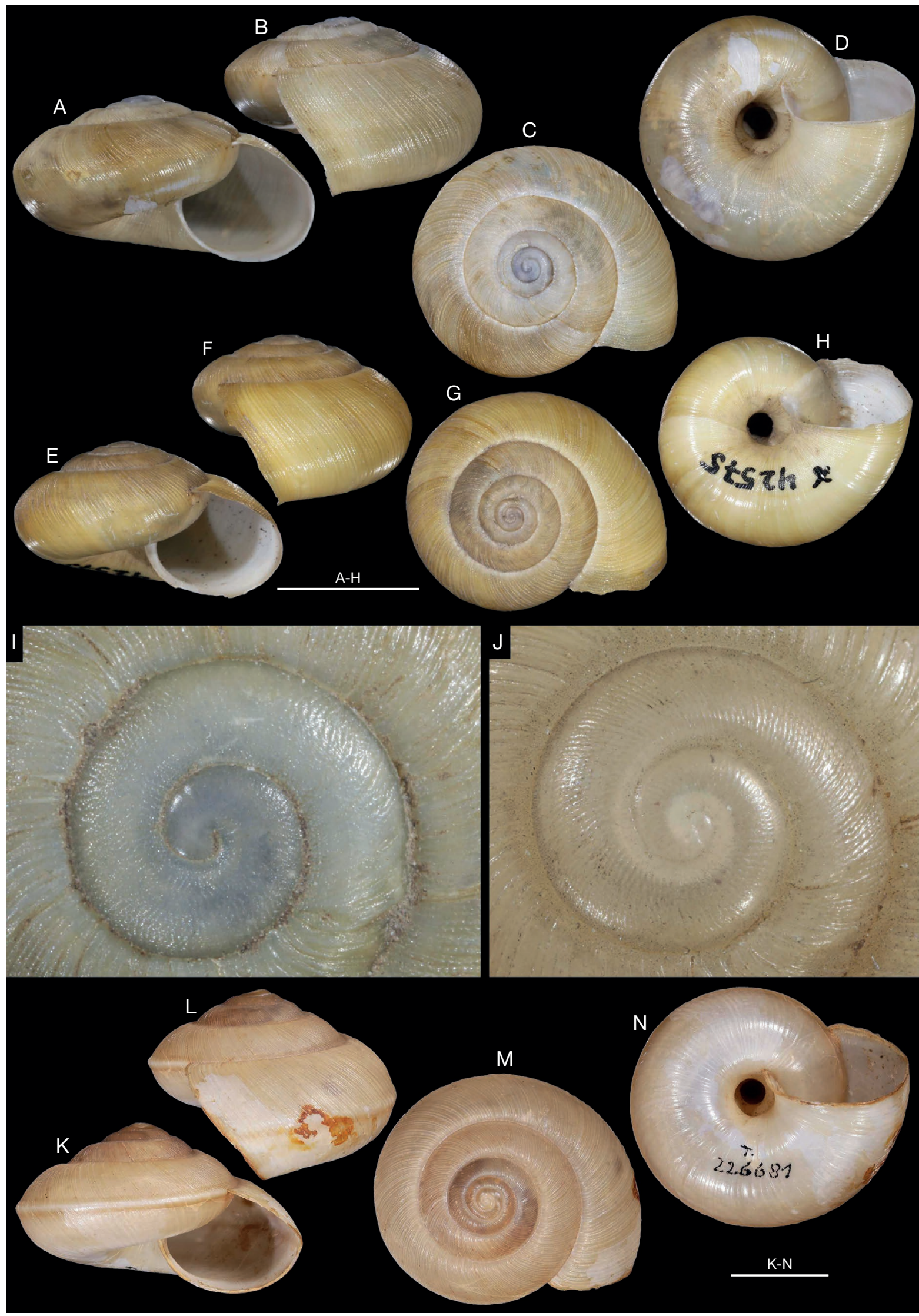

FIG. 7. - Shells of "Hemiplecta" species: A-D, Hemiplecta scrobiculata hupeiana (Gredler, 1887) (syntype, SMF 44672); E-I, Hemiplecta scrobiculata scrobiculata (Gredler, 1885), SMF 42575; J-H, Hemiplecta laotica (Möllendorff, 1899) (holotype, SMF 226681). Scale bars: 10 mm; I-J not to scale. 


\section{REMARKS}

Zilch (1974) found a single syntype in Bolzano in Gredler's collection.

\section{Hemiplecta (?) scrobiculata hupeiana (Gredler, 1887)} (Fig. 7A-D)

Zonites (Nanina?) scrobiculatus var. hupeina Gredler, 1887: 344-345.

Coccoglypta scrobiculata hupeina - Yen 1939: 153, pl. 15, fig. 63. Chen \& Gao 1987: 159, fig. 205.

Type material eXAmined. - China. Hu-bei (Hupei), coll. O. v. Möllendorff, ex coll. Gredler, SMF 42576/2 syntypes. - Hupé (Hupei), coll. G. Naegele, ex coll. Gredler, SMF 50091/1 syntype; China: Hubei (Hupei), coll. O. Boettger, ex coll. Gredler 1888, SMF 44672/1 syntype.

Additional material examined. — China. Hubei, Enshi Tujiazu Miaozu Zizhizhou, Enshi Shi, Mufucun SW 3 km, Enshi Daxiagu, Mother-child Affection; $30^{\circ} 26.029^{\prime} \mathrm{N}, 109^{\circ} 10.260^{\prime} \mathrm{E}$; A. Hunyadi leg.; 05.XI.2010; coll. HA/10 shells.

TyPe LOCALITY. — "Hupé".

DiFFERENTIAL DIAGNOSIS. - Hemiplecta scrobiculata hupeiana differs from the nominotypical subspecies by the larger, slightly keeled shell.

MEAsurements. - D: 20.1-23.3 mm, H: 10.9-12.4 mm ( $\mathrm{n}=4$ ).

\section{REMARKS}

The examined syntypes were taken from Gredler's collection to the Senckenberg Museum by Adolf Zilch (Zilch 1974).

\section{DISCUSSION}

Several hundreds of Asian camaenids have been described in the last two centuries, most intensively at the end of the 19 th and the beginning of the 20th centuries. However, the reproductive anatomy, which would allow more precise generic placements, is known from a small fraction of species only. Therefore, the species exclusively known from their shells are traditionally placed into "dustbin" genera. Furthermore, shells of Camaenidae (including Bradybaeninae) and Ariophantidae (including similar families such as Helicarionidae) can be both "helicoid", and thus, strikingly similar in appearance. As a result, reliably distinguishing between the two groups without knowing the reproductive anatomy may sometimes be difficult. Hemiplecta scrobiculata was originally placed in the genus Nanina Sowerby, 1842, which is now placed in the Ariophantidae (Schileyko 2002), and was later moved to Coccoglypta (Yen 1939). Although the teleoconch sculpture of C. scrobiculata is indeed strikingly similar to that of Coccoglypta, the different protoconch sculpture (Coccoglypta: practically smooth; Hemiplecta scrobiculata: finely reticulated) immediately tells that the two groups might not be closely related. Furthermore, the sharp (not expanded or thickened) peristome of Hemiplecta scrobiculata speaks against its affinity with the Camaenidae. Similarly, Chalepotaxis infantilis (Gredler, 1881), which looks like a bradybaenid with a sharp peristome, was placed in the Bradybaenidae by some, and in Helicarionidae by other authors; membership in the letter family being recently confirmed by Páll-Gergely et al. (2016).

We can find numerous ariophantid groups with a sculpture similar to that of Hemiplecta scrobiculata (dashed ribs on the teleoconch). However, the generic placement of Hemiplecta scrobiculata is difficult for to the unresolved genus-level classification of the Ariophantidae. The genus Elaphroconcha Gude, 1911, which inhabits the Indonesian islands, and Cryptozona Mörch, 1872 (treated as a subgenus of Ariophanta by Schileyko [2002]), which is widely distributed in Southeast Asia, have a finely tuberculated teleoconch, similar to that of Hemiplecta scrobiculata (Schileyko 2003). However, both genera have dot-like, narrow, sometimes even closed umbilici. The protoconch and teleoconch sculpture as well as the narrow, but open umbilicus of $H$. scrobiculata is reminiscent of Hemiplecta laotica (Möllendorff, 1899) (examined specimens: holotype: SMF 226681 [Fig. 7J-H], and three paratypes: SMF 226682). That species has recently been placed in Ariophanta Des Moulins, 1829 (Inkhavilay et al. 2019) and in Hemiplecta (Páll-Gergely 2019). It probably does not belong to Ariophanta, because the type species, Ariophanta laevipes, is known from southern India, and looks quite different (sinistral, banded, with very narrow umbilicus). The genus Oxytes (the subgenus where $H$. laotica has been originally placed to) also does not suit $H$. laotica, because its type species (Helix oxytes Benson, 1836) has irregular, but not dashed growth wrinkles on both protoconch and teleoconch (examined specimen: UMZC I.102145, probably syntype). The genus Phuphania Tumpeesuwan, Naggs \& Panha, 2007 has a narrow umbilicus, but similar sculpture to that of Hemiplecta scrobiculata (Tumpeesuwan et al. 2007, Tumpeesuwan \& Tumpeesuwan 2014). Ultimately Hemiplecta scrobiculata might deserve to be placed in its own genus, although we refrain from describing it without knowing the reproductive organs.

\section{Acknowledgements}

We are grateful to Sigrid Hof and Ronald Janssen for granting access to the collection of the SMF, to Richard Preece and Tom S. White for sending photos of the syntype of Helix oxytes, to Nicolas Raymond for taking photos of the syntype of Coccoglypta pinchoniana, to Liu Zheng-Ping and Kanji Okubo for providing specimens and to two reviewers for their comments on the manuscript. This study was supported by the MTA (Hungarian Academy of Sciences) Premium Post Doctorate Research Program to Barna Páll-Gergely.

\section{REFERENCES}

Bachmann O. \& Gredler V. 1894. - Zur Conchylien-Fauna von China. XVIII. Stück. Annalen des K.K. Naturhistorischen Hofmuseums 9 (3): 415-429.

Bouchet P., Rocroi J.-P., Hausdorf B., Kaim A., Kano Y., NÜTZel A., PARKhaev P., Schrödl M. \& Strong E. E. 2017. Revised classification, nomenclator and typification of gastropod and monoplacophoran families. Malacologia 61 (1-2): 1-526.

CASTRESANA J. 2000. - Selection of conserved blocks from multiple alignments for their use in phylogenetic analysis. Molecular 
Biology and Evolution 17: 540-552. https://doi.org/10.1093/ oxfordjournals.molbev.a026334

CHen D-N. \& GAO J.-X. 1987. - Economic Fauna of China (Terrestrial Molluscs). Science Press, Beijing, China. 186 p. (in Chinese)

Chen D.-N. \& ZHANG G.-Q. 2004. - Fauna Sinica (Invertebrata Vol. 37 Mollusca: Gastropoda: Stylommatophora: Bradybaenidae). Science Press, Beijing, China, 482 p. (in Chinese).

Deshayes G. P. 1870. - Diagnoses d'espèces nouvelles de mollusques terrestres et fluviatiles de la principaute de Moupin, Thibet oriental envoyees au Museum d'Histoire naturelle de Paris par M. l'Abbe Armand David missionnaire. Bulletin des Nouvelles Archives du Museum d'Histoire naturelle de Paris 6: 19-27.

Gittenberger E., Hamann T. D. \& Asami T. 2012. - Chiral Speciation in Terrestrial Pulmonate Snails. PLoS ONE 7 (4): e34005. https://doi.org/10.1371/journal.pone.0034005

GREDLER V. 1885. - Zur Conchylien-Fauna von China. VII Stück. Jahrbücher der Deutschen Malakozoologischen Gesellschaft 12: $219-235$.

GREDLER V. 1887. - Beschreibung neuer Arten und Varietäten. Jahrbücher der Deutschen Malakozoologischen Gesellschaft 14: 343-369.

HEUDE R. P. M. 1882. - Mémoires concernant l'histoire naturelle de l'empire chinois par des pères de la Compagnie de Jésus. Notes sur les Mollusques terrestres de la vallée du Fleuve Bleu. II, Mission Catholique, Chang-Hai, 88 p.

HEUdE R. P. M. 1885a. - Mémoires concernant l'histoire naturelle de l'empire chinois par des pères de la Compagnie de Jésus. Notes sur les Mollusques terrestres de la vallée du Fleuve Bleu. III, Mission Catholique, Chang-Hai, 89-132 p.

HEUDE R. P. M. 1885b. - Rectifications de nomenclature. Journal de Conchyliologie 33: 42-43.

Heude R. P. M. 1886. - Diagnoses Molluscorum novorum, in Sinis collectorum. Journal de Conchyliologie 34: 208-215.

INKHAVILAY K., SUTCHARIT C., BANTAOWONG U., CHANABUN R., Siriwut W., Srisonchai R., Pholyotha A., Jirapatrasilp P. \& PANHA S. 2019. - Annotated Checklist of the Terrestrial Molluscs from Laos (Gastropoda: Neritimorpha, Caenogastropoda and Heterobranchia). ZooKeys 834: 1-166. https://doi.org/10.3897/ zookeys. 834.28800

Johnson R. J. 1973. - Heude's Molluscan Types: or, Asian land and fresh water mollusks, mostly from the People's Republic of China, described by P. M. Heude. Special Occasional Publication, Department of Mollusks, Museum of Comparative Zoology, Harvard University, Cambridge, Massachusetts, 111 p. https:// doi.org/10.5962/bhl.title.141074

Kerney M. P. \& CAmERON R. A. D. 1979. - A Field Guide to the Land Snails of Britain and North-west Europe. Collins, London, 288 p.

MÖLLENDORFF O. VON. 1899. — Binnen-Mollusken aus Westchina und Central-Asien Ezhegodnik Zoologicheskago muzeia (Annals of the Zoological Museum of the Saint Petersburg Academy of Sciences) 4 (1): 46-144.

PÁlL-Gergely B. 2019. - A new species of Hemiplecta Albers, 1850 from Vietnam (Gastropoda: Pulmonata: Ariophantidae). Folia Malacologica 27 (2): 85-89. https://doi.org/10.12657/ folmal.027.007

Páll-Gergely B., Fehér Z., Otani J. U. \& Asami T. 2016. — An integrative taxonomic approach to infer the systematic position of Chalepotaxis Ancey, 1887 (Gastropoda: Stylommatophora: Helicarionidae). Molluscan Research 37 (2): 113-119. https:// doi.org/10.1080/13235818.2016.1234996

Pilsbry H. A. 1894-1895. - Manual of Conchology. Second Series: Pulmonata. Vol. 9 (Helicidae, Vol. 7). Academy of Natural Sciences Philadelphia, Philadelphia: 49-336 p.

Rambaut A. \& Drummond A. J. 2009. - Tracer: MCMC trace analysis tool, version 1.5. University of Oxford, Oxford. Available at: http://tree.bio.ed.ac.uk/software/tracer/

Ronquist F., Teslenko M., Van Der Mark P., Ayres D. L., Darling A., Höhna S., Larget B., Liu L., Suchard M. A. \&
Huelsenbeck J. P. 2012. - MrBayes 3.2: efficient Bayesian phylogenetic inference and model choice across a large model space. Systematic Biology 61 (3): 539-542. https://doi.org/10.1093/ sysbio/sys029

SCHILEYKo A. A. 2002. - Treatise on recent terrestrial pulmonate mollusks. 9. Helicarionidae, Gymnarionidae, Rhysotinidae, Ariophantidae. Ruthenica Supplement 2: 1167-1307.

SCHILEYKO A. A. 2003. - Treatise on recent terrestrial pulmonate mollusks. 10. Ariophantidae, Ostracolethaidae, Ryssotidae, Milacidae, Dyakiidae, Staffordiidae, Gastrodontidae, Zonitidae, Daudebardiidae, Parmacellidae. Ruthenica Supplement 2: 1309-1466.

SCHILEYKO A. A. 2004. - Treatise on Recent terrestrial pulmonate molluscs Part 12. Bradybaenidae, Monadeniidae, Xanthonychidae, Epiphragmophoridae, Helminthoglyptidae, Elonidae, Humboldtianidae, Sphincterochilidae, Cochlicellidae. Ruthenica Supplement 2: 1627-1763.

Tamura K., Stecher G., Peterson D., Filipski A. \& Kumar $S$. 2013. - MEGA6: molecular evolutionary genetics analysis, version 6.0. Molecular Biology and Evolution 30 (12): 2725-2729. https://doi.org/10.1093/molbev/mst197

Thompson J. D., Gibson T. J., Plewniak F., Jeanmougin F. \& Higgins D. G. 1997. — The CLUSTAL_X windows interface: flexible strategies for multiple sequence alignment aided by quality analysis tools. Nucleic Acids Research 25 (24): 4876-4882. https://doi.org/10.1093/nar/25.24.4876

TRYON G. W. 1887. - Manual of Conchology; Structural and Systematic. With Illustrations of the Species. Second series: Pulmonata. Volume III. Helicidae, Volume I., Published by the Author, Philadelphia, $313 \mathrm{p}$

TumpeEsuWAN C. \& TumpeesuWAN S. 2014. - Phuphania costata, a new species of dyakiid land snail (Pulmonata: Dyakiidae) from Phu Pha Lom limestone area, Loei Province, northeastern Thailand. The Raffles Bulletin of Zoology 62: 352-357.

Tumpeesuwan C., Naggs F. \& PanHa S. 2007. - A new genus and new species of dyakiid snail (Pulmonata: Dyakiidae) from the Phu Phan Range, northeastern Thailand. The Raffles Bulletin of Zoology 55 (2): 363-369.

Wade C. M., Mordan P. B. \& Naggs F. 2006. — Evolutionary relationships among the Pulmonate land snails and slugs (Pulmonata, Stylommatophora). Biological Journal of the Linnean Society 87: 593-610. https://doi.org/10.1111/j.1095-8312.2006.00596.x

Wade C. M., Hudelot C., Davison A., Naggs F. \& Mordan P. B. 2007. - Molecular phylogeny of the helicoid land snails (Pulmonata: Stylommatophora: Helicoidea), with special emphasis on the Camaenidae. Journal of Molluscan Studies 73: 411-415. https://doi.org/10.1093/mollus/eym030

WANG S. \& XIE Y. 2005. - China Species Red List (Vol. III, Invertebrates). Higher Education Press, Beijing: 368-369 p.

WU M. \& LIU Z. 2019. - The first proven oxychilid land snail endemic to China (Eupulmonata, Gastrodontoidea). ZooKeys 870: 33-50. https://doi.org/10.3897/zookeys.870.32903

YEN T.-C. 1936. - Some Quaternary gastropods from eastern Szechwan. Bulletin of the Geological Society of China 15 (3): 331342. https://doi.org/10.1111/j.1755-6724.1936.mp15003005.x

Yen T.-C. 1939. - Die Chinesischen Land-und Süßwasser-Gastropoden des Natur-Museums Senckenberg. Abhandlungen der Senckenbergischen Naturforschenden Gesellschaft, Frankfurt am Main, $234 \mathrm{p}$.

Zilch A. 1959-1960. - Handbuch der Paleozoologie, 6 (2) Euthyneura. Gebrüder Borntraeger, Berlin-Nikolassee, 834 p.

ZILCH A. 1974. - Vinzenz Gredler und die Erforschung der Weichtiere Chinas durch Franziskaner aus Tirol. Archiv für Molluskenkunde 104: 171-228.

Submitted on 4 January 2019; accepted on 8 April 2019;

published on 20 December 2019 


\section{APPENDIX}

Appendix 1. - Locality names mention in this manuscript.

\begin{tabular}{ll}
\hline Pinyin & Chinese \\
\hline Baiyun Cableway & 白云索道 \\
Baiyun Cun & 白云村 \\
Chaoyangdong & 朝阳洞 \\
Chengdu Shi & 成都市 \\
Chengkou & 城口县 \\
Chongqing Shi & 重庆市 \\
Chongzhou Shi & 崇州市 \\
Dujiangyan Shi & 都江堰市 \\
Fengqishan & 风栖山 \\
Fu-bien-ho & 抚边河 \\
Gansu & 甘肃省 \\
Guanwushan Forest Farm & 观雾山林场 \\
Heng-san-hsien & 衡山县 \\
Hen-kiou-fu & 衡州府 \\
Hen-san & 衡山 \\
Hubei & 湖北省 \\
Hu-bei & 湖北省 \\
Hunan & 湖南省 \\
Hupé (Hubei) & 湖北省 \\
Hupei (Hubei) & 湖北省 \\
Jiangyou Shi & 江油市 \\
Jiezi Zhen & 街子镇 \\
Jinbian Yan & 金鞭岩 \\
Jiusengdong & 九僧洞 \\
Kiun-tcheou & 均州(=丹江口市) \\
Mianyang Shi & 绵阳市 \\
Moupin & 穆坪(镇) \\
Muping Zhen & 穆坪镇 \\
Qingchenghoushan & 青城后山 \\
Qingchengshan & 青城山 \\
Shangqinggong & 上清宫 \\
Shuijingdong & 水晶洞 \\
Sichuan & 四川省 \\
Sy-tshuan (Sichuan) & 四川省 \\
Taian Zhen & 泰安镇 \\
Tchen K'eou (Chengkou) & 城口县 \\
Wudu Zhen & 武都镇 \\
\hline &
\end{tabular}

